study not only including the properties of the steel at a particular temperature but also the degree of persistence of these properties at that temperature over long periods of time. In this connexion, details were given of a creep test carried out on a heatresisting steel maintained under a load of $280 \mathrm{lb}$. per sq. inch for a period of 10,000 hours at $900^{\circ} \mathrm{C}$. With reference to the production of permanent strain at normal temperatures, Dr. Hatfield instanced a test now in progress at the Brown-Firth Research Laboratories. The experiment consists of a strip of cold-worked austenitic steel placed in tension under a stress of 25 tons per square inch. The test was commenced in June 1929, and since that date the extension has been nil within the accuracy of measurement applied, that is, a sensitivity of $1 / 40,000$ of an inch and a gauge length of 8 inches. In discussing the results achieved by the addition of alloying elements, Dr. Hatfield stated that, experimenting upon the basis of the rustless steel composition by modifying the chromium and nickel, and by adding other elements such as tungsten, molybdenum, cobalt or titanium, steels have been produced which maintain a reasonably protective film at temperatures even in excess of $1000^{\circ} \mathrm{C}$., besides possessing a useful strength.

\section{Palæolithic Man in Northern England}

Arthough it is more than sixty years since the late Sir William Boyd Dawkins brought to light evidence of the presence of man during the Upper Palæolithic period in the north Midland region of England, it was not until Mr. A. Leslie Armstrong's investigations in the cave and other deposits of the area in a series of systematic researches, which began in 1921, that it became possible to establish a chronological succession in human occupation here in the course of the palæolothic age, and its relation to phases of the Ice Age. The results of these investigations were surveyed by Mr. Armstrong in his Wilde Lecture before the Manchester Literary and Philosophical Society on March 14. In dealing with the earlier evidence of occupation, he pointed out that until three years ago it had not been known that the range of Lower Palæolithic man extended to the northern Midlands, but intensive research directed to the contents of the glacial drift and old river terrace gravels of the Trent and its tributaries had provided evidence of his presence there in the form of hand-axes of flint and other artefacts, representing all the Lower Palæolithic cultures. Excavations in the Pin Hole Cave, Creswell, revealed three zones of occupation in Mousterian times, including two cold periods. Mr. Armstrong's Trent Valley researches indicate that the lower terrace gravels of the river approximate in time to the second Mousterian occupation of the cave, and that they were laid down during one, or possibly both, of the cold periods recorded in the cave. Rock shelters in the Creswell gorge and neighbouring valleys and habitation sites on the Lincolnshire cliff, covered by solifluxion deposits, indicate that man lived in these regions while events which mark the final glaciation of England were active in the east, west and north of the region; therefore human occupation of the north Midland area throughout palæolithic times can now be demonstrated.

\section{Archæological Finds in the Nile Delta}

AN archæological discovery described as "exceptionally important" is reported from the ancient city of Tanis in the Sharkia Province of the Nile Delta (The Times, March 20). Prof. Montet of Strasbourg, who has been engaged for some years in excavating on the site, on which both Mariette Pasha and Sir Flinders Petrie carried out archæological investigations, has discovered the first gold coffin to be found in Egypt since that of Tutankhamen, and a silver sarcophagus, the first example in that metal from Egypt. Tanis was the capital of Egypt between the Thirteenth and Eighteenth Dynasties; but the present find was made in excavating a series of funerary chambers of the tombs of kings of the Twenty-first and Twenty-second Dynasties (1100950 B.c.), the capital of which was Tell Basta, the site of the modern Zagazig. Hitherto there has been no certain knowledge of the residence of these kings. The funerary chambers were empty, but a few days ago a narrow corridor was found leading to a wall which, when pierced, gave entry to an intact chamber of medium size, built of white limestone, and containing a gold sarcophagus. Within this sarcophagus was a second of silver, in which was a mummy. Inscriptions show that it is that of King Shishak. Two human skeletons still wearing ornaments were found on either side of the sarcophagus; and there were many jewels among the remains. In one corner of the tomb were funerary statuettes representing King Cumin, and in another corner a large vase, which has yet to be opened.

\section{Libraries in Technical Institutions}

A REPORT on libraries in technical institutions, which has been issued by a joint committee of the Association of Technical Institutions, the Association of Principals of Technical Institutions and the Association of Teachers in Technical Institutions, should be of considerable service to those responsible for providing and maintaining library services in technical colleges (Loughborough: Loughborough College, 1939). In addition to a clear analysis of the aims of such a library service, which should assist in the formulation of sound policy based on well-defined principles, it gives sufficient detail in regard to such matters as accommodation and planning to be of real service in the design of a new library or expansion of existing services. A feature of the report is the inclusion of plans and details not only of three distinct types of library design but also of a number of representative libraries. The basic recommendation of the report is that in every technical institution there should be at least one room of adequate size reserved solely as a library, containing an ample supply of books and periodicals kept thoroughly up to date and covering all departments of work carried out in the institution, and including also a good 